\title{
Charakter indikátorů udržitelného rozvoje a indikátorů vzdělávání pro udržitelný rozvoj na mezinárodní úrovni
}

Svatava Janoušková, Tomáš Hák, Jan Maršák, Lenka Pachmanová

Envigogika 2010/V/3- Recenzované články/ Reviewed Papers

Publikováno/Published 28. 12. 2010

DOI: http://dx.doi.org/10.14712/18023061.57

\begin{abstract}
Abstrakt:
Článek se zaměřuje na př́stupy, jimiž jsou monitorovány a vyhodnocovány vzdělávací aspekty v koncepci udržitelného rozvoje a vzdělávání pro udržitelný rozvoj na mezinárodní úrovni. Na základě obsahové analýzy raady dokumentů vztahujících se jak ke koncepci udržitelného rozvoje, tak ke koncepci vzdělávání pro udržitelný rozvoj, a sad indikátorů, které tyto dokumenty doprovázejí, docházejí autoři k tomu, že indikátory vzdělávání monitorující implementaci a dosahování cílů, at' už strategií udržitelného rozvoje nebo strategií vzdělávání pro udržitelný rozvoj, převažují procedurální indikátory, zpravidla kvantitativního charakteru. Autoři v textu zdưrazňují skutečnost, že koncepce udržitelného rozvoje úzce souvisejí s lidskými postoji a hodnotami a jejich proměnami vyvolanými mj. různými formami vzdělávaní. $V$ závěru článku proto autoři navrhují, že by bylo velmi žádoucí doplnit existující indikátorové sady o indikátory popisující právě proměnu lidských postojů a hodnot.
\end{abstract}

\section{Klíčová slova:}

Indikátory udržitelného rozvoje, indikátory vzdělávání pro udržitelný rozvoj, lidské hodnoty, vzdělávání pro udržitelný rozvoj

\begin{abstract}
:
The main issue of the paper is to show how the educational aspects of the sustainable development concept or various aspects of education for sustainable development are monitored and evaluated on the international level. Based on a content analysis of selected documents related to the above concepts, as well as on the analysis of the indicator sets that these documents follow, the authors state that the indicators that monitor and evaluate progress in sustainable development and education are mostly procedural and quantitative ones. The authors emphasize that the concept of sustainable development is strongly value and attitude oriented, and changes in values and attitudes are, inter alia, affected by different types of education. Thus they suggest widening the existing indicator sets (related to sustainable development strategies, as well as to strategies of education for sustainable development), and adding changes in human values and attitudes to the indicators for monitoring and evaluating.
\end{abstract}




\section{Key words:}

Sustainable development indicators, indicators of education for sustainable development, human values, education for sustainable development 


\section{Úvod}

Pokud si do vyhledavače na internetu zadáte český výraz udržitelný rozvoj nebo jeho anglický ekvivalent sustainable development, získáte širokou škálu odkazů. Na tento výraz narazíte $\mathrm{i} v$ dalších médiích, např. novinách a pozornost je mu mezi jinými tématy čas od času věnována i v televizi či rozhlasu. Udržitelný rozvoj totiž představuje jednu z nejpropracovanějších koncepcí dlouhodobého rozvoje společnosti. Je předmětem řady politických rezolucí, deklarací, strategií a opatření at' už na mezinárodní, národní nebo lokální úrovni a veřejnost je prostřednictvím médií o vývoji situace $v$ této oblasti poměrně dobře informována. Přenos informací k veřejnosti je totiž jednou ze základních podmínek udržení zájmu veřejnosti o tuto koncepci, a není to náhoda.

Pojem udržitelného rozvoje se poprvé objevuje již na konci sedmdesátých let 20. století ve strategii nazvané Strategie zachování světa (World Conservation Strategy), kterou prosazuje mezinárodní organizace s názvem Světový svaz ochrany prírody (IUCN ${ }^{1}$, 1980). Významnější pozornosti se ale ideji udržitelného rozvoje dostává v roce 1987, kdy vychází známá zpráva G. H. Brundtlandové s názvem "Naše společná budoucnost". Zde je pojem udržitelného rozvoje totiž podrobněji specifikován. Zpráva pojednává o udržitelném rozvoji v tomto významu: "Udržitelný rozvoj je takový zpưsob rozvoje, který uspokojuje potřeby prítomnosti, aniž by oslaboval možnosti budoucích generací naplňovat jejich vlastní potreby." (World Commission on Environment and Development, 1987, v českém překladu 1991). Definice uvedená $v$ této zprávě se potom stává jednou z nejčastěji citovaných definic pojmu udržitelný rozvoj a je užívána doposud.

Z definice, kterou formulovala G. H. Brundtlandová, vyplývá, že udržitelný rozvoj má úzký vztah k lidským potřebám a hodnotám a zaměřuje se na lidský blahobyt v kontextu okolního prostředí, samozřejmě s ohledem na další generace. Vyjdeme-li z konceptu Abrhama Maslowa (viz Maslow, 1968/1999), pak můžeme okolní prostředí chápat jako prostředek, který nám umožňuje naplnit naši hierarchii potřeb. Podle Maslowa jsou potřeby uspořádány do pětistupňové pyramidy, kde v jejím nejnižším stupni se nacházejí fyziologické potřeby člověka, nad nimi potřeba bezpečí, výše potřeba lásky, dále úcty a na nejvyšším stupni se nachází potreba seberealizace. Maslow konstatoval, že v pyramidě níže položené potřeby jsou pro lidský život významnější, a teprve jejich alespoň částečné naplnění je podmínkou pro vznik (a touhu po naplnění) potřeb v pyramidě umístěných výše, tedy potřeb méně naléhavých. $V$ některých, někdy extrémních situacích lidského života, ovšem platí, že potřeby vyšší (např. estetické nebo duchovní) mohou do určité míry saturovat ty nižší hladiny potřeb, které jsou z jakýchkoli důvodů omezeny. Naplnění všech potřeb v rámci pyramidy vede ke spokojenému lidskému životu, což by mimo jiné mohlo být podmínkou pro nesobecké chování člověka vưči okolnímu prostředí.

Zdá se ovšem, že lidské potřeby mohou růst velmi rychle, jak o tom svědčí např. prudký nárůst spotřeby potravin ve vyspělých zemích dokladovaný zprávou Světové zdravotnické organizace (WHO, 2003). To se ale samozřejmě neobejde bez zásahů do okolního prostředí. Právě proto je tak důležitá koncepce udržitelného rozvoje, která do vztahu k lidským potřebám a blahobytu dává též lidský hodnotový systém a zdưrazňuje fakt, že pro naplnění celé hierarchie potřeb stačí ze subjektivního hlediska jejich částečné naplnění, nikoli naplnění úplné. Lidské hodnoty a pochopení vztahů mezi člověkem a př́rodním prostředím se tak stávají důležitými faktory na poli udržitelného rozvoje (představují regulační prvek jinak subjektivně „nekonečných" lidských potřeb). Což si uvědomují nejen vědci v oblasti pedagogiky, psychologie a sociologie, ale také pracovníci decisní sféry. Proto je i vzdělávání pro udržitelný rozvoj věnována značná pozornost.

${ }^{1}$ IUCN je zkratkou anglického „International Union for Conservation of Nature”. 


\section{Vzdělávání v kontextu mezinárodních strategií udržitelného rozvoje}

Je tedy zřejmé, že vzdělávání, a to na všech jeho stupních a ve všech formách (formální, neformální, informální), mưžeme považovat, pokud bychom použili matematické terminologie, za podmínkou nutnou, nikoli však postačující pro úspěšné naplňování principů udržitelného rozvoje. Také proto $v$ málokteré z mezinárodních deklarací nebo strategií, které se k problematice udržitelného rozvoje vztahují, aspekt vzdělávání chybí. Minimálně je zde snaha přenášet relevantní informace směrem k veřejnosti a zvyšovat tím její povědomí o zásadních otázkách vztahujících se k udržitelnému rozvoji (viz např. Šremer, 2007). Tuto snahu chceme dokumentovat pomocí tabulky 1 (viz Závěr).

Z tabulky 1 je patrné, že strategie udržitelného rozvoje reflektují vzdělávání v různé míře. Zatímco Deklarace o životním prostředí a rozvoji z Ria hovoří o vzdělávání zejména v informální rovině, tedy ve smyslu nutnosti informovat jednotlivce o otázkách životního prostředí z důvodů jejich možné participace $v$ různých rozhodovacích procesech, pak Akční program k této strategii (Agenda 21, 1993, v českém překladu 2000) už vzdělávání chápe v širších souvislostech. Další strategie (např. strategie OECD, EC nebo Obnovená strategie udržitelného rozvoje EU) se pak vzděláváním zabývají v širším kontextu (tedy nejen z hlediska nutnosti přenosu informací). Zasahují často už i do úrovně formálního vzdělávání v jednotlivých státech, jež strategii ratifikují. Zdá se tedy, že vzdělávání je vnímáno jako stále dưležitější faktor při dosahování cílů udržitelného rozvoje a tvưrci strategií si uvědomují nezbytnost role vzdělávání při prosazování konkrétních cílů, at' už v oblasti sociální, environmentální nebo ekonomické. Není proto překvapující, že strategie vztahující se k udržitelnému rozvoji v nejširším kontextu uvádějí taková prohlášení jako: „Vzdělávací systém hraje důležitou roli v utváření lepšího porozumění cílưm udržitelného rozvoje, podpoře vnímání individuální i kolektivní odpovědnosti, a z toho plynoucí podpoře změny chování." (EC, 2001). Nebo: "Vzdělávání je předpokladem pro podporu změn chování a předávání takových klíčových kompetencí všem občanům, které jsou nutné pro dosažení udržitelného rozvoje. Úspěch ve zvrácení neudržitelných trendư společnosti bude do značné míry záviset na vysoce kvalitním vzdělávání pro udržitelný rozvoj na všech úrovních vzdělávání, a začlenění takových témat, jakými jsou udržitelná spotřeba energii a fungování dopravního systému, vzorce udržitelné spotřeby a výroby, zdraví, mediální kompetence a zodpovědné globální občanství." (EU, 2006).

\section{Mezinárodní strategie vzdělávání pro udržitelný rozvoj a jejich implementace na př́íkladu České republiky}

Význam vzdělávání v problematice udržitelného rozvoje je dále podtržen vytvářením paralelních rezolucí a strategií, které se věnují výhradně vzdělávání, výchově a osvětě v této problematice. Mezi nejvýznamnější iniciativy v této oblasti patří bezesporu Dekáda OSN vzdělávání pro udržitelný rozvoj 2005-2014 (UNGA, 2002) a UNECE Strategie vzdělávání pro udržitelný rozvoj (UNECE, 2005)². Hlavní cíle v těchto strategiích jsou shrnuty v tab. 3 [viz Závěr]. Ve svém znění jsou zmíněné vzdělávací strategie provázány s řadou cílů a principů udržitelného rozvoje na mezinárodní úrovni. Dávají tak možnost (při jejich ratifikaci) logicky propojovat na národní úrovni jednotlivé cíle a opatření a tak komplexně přistupovat k problematice udržitelného rozvoje.

2 Tato strategie Hospodářské komise pro Evropu, výboru pro environmentální politiku (United Nation Economic Commision for Europe), je také označována jako Vilniuská strategie. 
Tradice toho, co s trochou nadsázky můžeme nazvat zárodkem udržitelného rozvoje, redukovaného ovšem zejména na složku environmentální, se v různých strategických dokumentech vztahujících se ke vzdělávání, projevuje již od výše zmíněných sedmdesátých let minulého století. Za všechny aktivity připomeňme zejména Konferenci o environmentálním vzdělávání (Conference of Environmental Education) konanou v Tbilisi v roce 1977 nebo Kongres o environmentálním vzdělávání a výcviku (Congress on Environmental Education and Training) konaný v Moskvě v roce 1987 (UNESCO-UNEP, 1987). Právě tyto aktivity vedly $\mathrm{k}$ zařazení celé škály důležitých environmentálně orientovaných témat do národních kurikul řady zemí a environmentální vzdělávání se tak stalo neopomenutelnou složkou formálního vzdělávání, at už jako samostatný obor/téma nebo spiše jako součást (zejména) prírodovědných vzdělávacích oborů na úrovni primárního, nižšího a vyššího sekundárního vzdělávání.

Začleňování ratifikovaných vzdělávacích strategií udržitelného rozvoje až do úrovně školního kurikula mǔžeme demonstrovat na př́kladu České republiky. V České republice byla environmentální témata $v$ nižším sekundárním vzdělávání až donedávna neopomenutelnou složkou zejména př́rodovědných oborů- př́rodopisu/biologie, chemie, fyziky a zeměpisu/geografie (zasahující jak do prírodovědné, tak společenskovědní oblasti), a to již od 70 . let. Ke změně došlo zavedením Rámcového vzdělávacího programu pro základní vzdělávání (RVP ZV, 2005), který reflektoval požadavky Evropské unie na posílení environmentálního vzdělávání, resp. vzdělávání pro udržitelný rozvoj $v$ rámci členských států EU. Kromě témat imanentních konkrétním vzdělávacím oborům (zeměpisu, chemii, fyzice, př́rodopisu, výchově k občanství, aj.) bylo navíc do výuky zařazeno také pro školy závazné prưřezové téma Environmentální výchova. Trend integrace daného tématu do výuky pak pokračuje i v oblasti vyššího sekundárního vzdělávání a projevuje se v Rámcovém vzdělávacím programu pro gymnázia (RVP G, 2007) i ve většině vzdělávacích programů středních odborných škol. Přestože průřezové téma nese název Environmentální výchova, do určité míry pokrývá také některé aspekty vzdělávání pro udržitelný rozvoj.

Spolu s implementací rezolucí a strategií vyjádřených ve dvou výše uvedených dokumentech UN a UNECE se postupně začíná i v národních vzdělávacích strategiích jednotlivých zemí věnovat zvýšená pozornost právě udržitelnému rozvoji, představujícímu širší téma než samostatná environmentální problematika. Zdá se tedy, že podobně, jako se postupně začalo promítat environmentální vzdělávání od sedmdesátých let $v$ řadě národních kurikul evropských a mimoevropských zemí, tak se postupně budou v národních kurikulech stále více prosazovat rovněž témata související s udržitelným rozvojem, zahrnující tedy nejen oblast environmentální.

Např́klad $v$ České republice je problematika udržitelného rozvoje (z hlediska vzdělávání) jedním z důležitých témat, jímž se zabývá Výzkumný ústav pedagogický v Praze, který je v naší zemi zodpovědný za tvorbu kurikula pro všeobecné vzdělávání. Tento ústav tak např. pomáhá implementovat některé důležité principy Strategie vzdělávání pro udržitelný rozvoj ČR 2008-2015 (viz SVUR, 2008), na jejíž přípravě se podílel a která začleňuje UNECE strategii do národní úrovně vzdělávání. Významnou oporou $v$ těchto iniciativách je také silná základna nevládních neziskových organizací, které se environmentálním vzdělávám, resp. vzděláváním pro udržitelný rozvoj, zabývají. Ty navíc zasahují nejen populaci dětí a mládeže, ale rovněž dospělých. Významná je v této oblasti také činnost univerzit a vysokých škol v oblasti terciárního vzdělávání.

Chceme-li získat objektivní data, resp. informace o výsledcích vzdělávání v oblasti udržitelného rozvoje at́ na úrovni lokální (školami a nevládními neziskovými organizacemi počínaje a úrovní obcí konče), národní či mezinárodní úrovni, musí být tyto aktivity patřičným způsobem sledovány, monitorovány. To se však neobejde bez vytváření určitých indikátorů či souborů neboli sad indikátorü, jež nám výše zmíněná objektivní data umožní porovnávat a analyzovat. My se $v$ následujících odstavcích budeme věnovat indikátorům vzdělávání vztaženého k problematice udržitelného rozvoje vytvářeným na mezinárodní úrovni. 


\section{Indikátory vzdělávání jako složka indikátorů udržitelného rozvoje}

\section{Mezinárodní indikátory udržitelného rozvoje a jejich vztah k indikátorům vzdělávání}

Účelem indikátorů, v nejobecnějším slova smyslu, je objektivní a pokud možno spolehlivé sledování vlastností objektů (nebo systémů těchto objektů) daného druhu, či procesů, které v těchto objektech či mezi nimi probíhají (Janoušková \& Maršák, 2008). Zmíněné objekty mohou být fyzikální (např. atomy či planety), chemické (molekuly a jejich systémy), biologické (živé systémy) či sociální (např. rodiny, školy, vzdělávací systémy, ekologické systémy).

V užším pojetí pak Ize indikátory považovat za nástroje vytvářené a zaváděné za účelem hodnocení a informování, tedy zejména proto, aby umožnily posoudit, zda bylo dosaženo předem definovaných záměrư resp. cílư vymezených $v$ dané oblasti zkoumání a zda jsou za daných podmínek záměry resp. cíle dosahovány optimálním způsobem (viz např. Ogawa and Collom, 2000; Shavelson et al., 1991; Dlouhá, 2007)

Takové indikátory zpravidla doprovázejí v sadách většinu iniciativ v podobě rezolucí, deklarací, strategií, opatření nebo politik, přičemž jejich hlavním smyslem je posouzení, do jaké míry bylo dosaženo vytčených cílů a eventuálně jak efektivně se tak stalo (např. z hlediska časového nebo finančního). Indikátory tedy slouží v tomto prípadě také jako evaluační nástroj a do značné míry také jako nástroj komunikace mezi decisní sférou a odbornou veřejností, resp. decisní sférou a laickou veřejností na mezinárodní úrovni i v národních podmínkách.

Indikátory udržitelnosti $v$ nejširším smyslu slova používané na mezinárodní úrovni vykazují všechny výše uvedené aspekty, přičemž jejich využití navíc umožňuje srovnání jednotlivých parametrů udržitelnosti mezi konkrétními státy, eventuálně sestavení pořadí/žebříčku zemí z hlediska naplňování cílů vytyčených v oblasti udržitelného rozvoje na mezinárodní úrovni. Je to přirozeně dáno tím, že at už se indikátor týká environmentálních aspektů udržitelnosti či sociálních aspektů (mezi něž bezpochyby vzdělávání zařazujeme), vymezení významu pojmu indikátoru zůstává stejné či podobné, jak jsme uvedli výše.

Pro účely srovnávání států či vytváření žebřičků je nejvhodnější volba kvantitativních indikátorů (spíše než indikátorů kvalitativních), které tyto komparace respektive vytváření pořadí/žebřičků umožňují. Deskripce ve všech aspektech udržitelnosti se totiž pohybuje na vysoké úrovni obecnosti proto, aby mohlo vzhledem k značným odlišnostem srovnávaných zemí (zejména pak voblasti sociální, kulturní, politické a ekonomické) vůbec $\mathrm{k}$ těmto analýzám docházet.

Zaměříme se nyní na vybrané sady indikátorů udržitelného rozvoje, které jsou zaváděny na mezinárodní úrovni, a budeme sledovat výskyt indikátorů vzdělávání (jako složky indikátorů sociálních) v těchto sadách. Předmětem našeho zájmu budou výhradně složené indikátory (indexy) a indikátorové sady jako např. Index environmentální udržitelnosti (Environmental Sustainability Index), Index lidského rozvoje (Human Development Index) nebo Rozvojové cíle tisíciletí (United Nations Millenium Development Goals), kde jsou indikátory vzdělávání jednoznačně složkou sledovaných sociálních indikátorů. Vzhledem k charakteru a účelu textu se nezabýváme dalšími indikátory udržitelnosti, jakými jsou např́klad Ekologická stopa (Ecological Footprint) nebo Index živoucí planety (Living Planet Index), které jsou zaměřeny zejména na environmentální aspekty udržitelnosti. $\mathrm{V}$ centru našeho zájmu nestojí ani indikátor Index blahobytu (Well Being Index) nebo Index environmentální výkonnosti (Environmental Performance Index), které se v sociálních parametrech vzdělávání neuvažují.

Přehled o vybraných indikátorových sadách a charakteru indikátorů vzdělávání v nich obsažených podává tabulka 2. [viz Závěr] 


\section{Charakter indikátorů vzdělávání jako součásti mezinárodních indikátorů udržitelného rozvoje}

Na první pohled je zřejmé, že indikátory užívané v sadách indikátorů udržitelného rozvoje na mezinárodní úrovni, které uvažují vzdělávání jako jeden z ukazatelů udržitelnosti v sociální oblasti, se zaměřují zejména na ty aspekty vzdělávání, které mohou být měřitelné zejména kvantitativními metodami a jsou obsaženy ve většině národních eventuálně mezinárodních statistik (např. statistik OECD nebo UNESCO). Jedná se např. o počty žáků/studentů $v$ jednotlivých stupních vzdělávání v daném období, dále poměr studujících mužů a žen v jednotlivých stupních vzdělávání, počet absolventů s dokončeným vzděláním ( $v$ jednotlivých stupních - primárním, sekundárním a terciárním) eventuálně přístup k informačním technologiím. Je zřejmé, že takové indikátory, které $v$ pedagogice nazýváme indikátory vzdělávání, poskytují sice významnou informaci, ale informaci velmi všeobecnou, která nevypovídá např́klad nic o zařazování problematiky udržitelného rozvoje do národních kurikul, tedy do formálního vzdělávání, o podpoře projektů organizací působících v oblasti neformálního vzdělávání, které se na danou problematiku zaměřují, nebo o úrovni přenosu informací mezi zaangažovanými skupinami a dalších důležitých procesech, které vedou ke zvyšování a vybavování běžné populace kompetencemi, které jsou důležité pro dosažení udržitelného rozvoje jako takového, jak uvádí již shora uvedená Obnovená strategie udržitelného rozvoje EU.

Je však také zřejmé, že charakter indikátorů udržitelného rozvoje nemůže být v mezinárodním měř́tku jiný. Za prvé proto, že jakékoli indikátory, včetně indikátorů vzdělávání, mají na mezinárodní úrovni vysoký stupeň obecnosti, aby vůbec k nějakému srovnání vzdělávacích systémů jednotlivých zemí mohlo dojít, za druhé proto, že vzdělávání je pouze jedním z mnoha aspektů na úrovni indikátorů pro udržitelný rozvoj. Navíc indikátory vzdělávání $v$ těchto strategiích nemusí mít ani charakter indikátorů posuzujících výhradně kvalitu vzdělávání (ve významu měřitelné žádoucí úrovně fungování anebo produkce vzdělávacích procesů, institucí nebo systémů (viz (Prưcha 2000)), ale mohou sloužit k jiným účelưm. Např. k posuzování snižování chudoby, k posuzování míry odstraňování nerovností mezi muži a ženami, etnickými skupinami apod.

Je proto logické, že se vzdělávání pro udržitelný rozvoj se z celé problematiky vydělilo a vytváří jak samostatné (konkrétnější) strategie týkající se vzdělávání, výchovy a osvěty ve vztahu k udržitelnému rozvoji, jak jsme uvedli v úvodu, tak samostatné indikátory vztahující se $\mathrm{k}$ těmto strategiím. K nárưstu počtu a plošnější aplikaci těchto indikátorů pak dochází zejména v současném období, kdy probíhá Dekáda OSN vzdělávání pro udržitelný rozvoj 2005-2014 a potřeba monitoringu pomocí indikátorů tak nabývá na významu.

\section{Indikátory vzdělávání pro udržitelný rozvoj na mezinárodní úrovni}

Mezi první iniciativy ve vytváření indikátorů vzdělávání pro udržitelný rozvoj patří iniciativa organizace UNECE. Účelem těchto indikátorů je monitoring pokroku států v implementaci mezinárodní strategie (UNECE / Vilniuské strategie) a zároveň zhodnocení prímých dopadů implementace této strategie na národní úrovni států, jež ji ratifikovaly. Indikátory ${ }^{3}$, které jsou ke strategii vytvořeny, jsou jednak kvantitativního jednak

\footnotetext{
3 Rozlišovány jsou hlavní indikátory, např. operační rámec pro podporu prosazování VUR, hlavní témata UR uplatňovaná ve formálním vzdělávání, př́ležitost kooperace vzdělavatelů VUR, existence učebních materiálů a pomůcek pro VUR, diseminace výsledků výzkumů; k těmto hlavním indikátorům jsou vždy přiřazovány sub-indikátory.
} 
kvalitativního rázu. Členěny jsou prozatím v šesti hlavních cílových kategoriích ${ }^{4}$ podle charakteru do čtyř typových skupin (UNECE Expert Group, 2008):

1) Checklist Indicators ${ }^{5}$ (dotazníkové/ výchozí indikátory) přinášejí informaci o výchozí politické situaci, legislativě, řízení a procesech přijatých a uskutečňovaných vládou. Sem patří sub-indikátory typu: Je strategie dostupná v národních jazycích?, Je vzdělávání pro udržitelný rozvoj ve vaší zemi součástí politiky udržitelného rozvoje, pokud tato politika existuje?, Máte nástroje pro hodnocení neformálního a informálního vzdělávání? $\mathrm{Na}$ dané položky Ize zpravidla odpovídat ano/ne/nezodpověditelné, v některých případech je po státech vyžadována doprovodná slovní odpověd'.

2) Input Indicators (vstupní indikátory) zprostředkovávají informaci o širším spektru aktivit, které napomáhají implementaci strategie. Mezi sub-indikátory posuzující tento aspekt se řadí např. indikátory typu: Do jaké míry se podílí na vzdělávání pro udržitelný rozvoj neformální vzdělávání? (odpověd' se zaznamenává na škále), Do jaké míry jsou vládou podporovány sítě/platformy vzdělavatelů, kteří se vzděláváním pro udržitelný rozvoj zabývají? (vyjádření v \% podpory vlády sítím vzdělávání pro udržitelný rozvoj oproti jiným sítím). Má implementovaná strategie mechanismy pro podporu vývoje a produkce nástrojů a materiálư pro vzdělávání pro udržitelný rozvoj?

3) Output Indicators (výstupní indikátory) přinášejí informaci o možném dopadu prímých výstupů realizovaných aktivit vázaných na strategii. Sem patří subindikátory typu: Do jaké míry vyvíjely skupiny vzdělavatelů ve vzdělávání pro udržitelný rozvoj vlastní indikátory? Kolik existuje sítí nebo platforem, které se zabývají problematikou vzdělávání pro udržitelný rozvoj? Existují vědecké publikace o vzdělávání pro udržitelný rozvoj?

4) Outcome indicators (výsledkové indikátory) zprostředkovávají informaci o možném dopadu implementace strategie specificky s ohledem na hodnoty, postoje a volby spojené s pozitivním přijetím udržitelného rozvoje. Oblast je charakterizována takovými sub-indikátory, jaké reprezentují odpovědi na otázky např.: Jsou vyhodnocovány změny jedinců ve znalostech, postojích a jednání z hlediska udržitelného rozvoje na základě pưsobení neformálního nebo informálního vzdělávání? Oproti ostatním oblastem je tato skupina poněkud méně zastoupena. (UNECE, 2008, Tilbury, 2007)

Cílem těchto indikátorů není ani tak posuzování států a výsledků jejich aktivit, ani vytváření žebříčků pořadí, ale spíše (vzájemné) poučení se v dané oblasti (Tilbury, 2007). Indikátory mají státům umožnit reflektovat efektivitu implementace jejich národních strategií.

Lze konstatovat, že zatímco kategorie pro posuzování jakými jsou implementace národních politik vzdělávání k udržitelnému rozvoji, podpora vzdělávání pro udržitelný rozvoj nebo způsob vzdělávání v rámci vzdělávání pro udržitelný rozvoj (např. počet subjektů prosazující vzdělávání pro udržitelný rozvoj v neformálním vzdělávání) jsou podrobně rozpracovány pomocí indikátorů, pak tolik akcentovaná změna ve znalostech, postojích a jednání jedinců vưči životnímu prostředí příliš indikátorově ukotvena není.

Druhou iniciativou, která se zabývá vývojem indikátorů vzdělávání pro udržitelný rozvoj, je uskupení UNESCO-IUCN-CEC ${ }^{6}$-Asia Pacific. Toto uskupení se snaží o identifikaci

\footnotetext{
${ }^{4}$ Vztahují se k hlavním cílům strategie (viz tabulka 3)

5 Př́klady všech dále uváděných indikátorů UNECE strategie budou doloženy na sub-indikátorech, které čtenáři umožní lépe se v daném indikátorovém typu orientovat.
}

${ }^{6}$ CEC - Commision on Education and Communication 
indikátorů vhodných pro hodnocení pokroku v rámci Dekády OSN vzdělávání pro udržitelný rozvoj 2005-2014 v rámci Asijsko-pacifického regionu s tím, že vytvářené směrnice mohou být vodítkem i pro další země, které pokrok v rámci dekády chtějí hodnotit. Směrnice, které byly k tomuto tématu vytvořeny (viz UNESCO Bankog, 2007) dělí indikátory podle charakteru do třech hlavních kategorií, které obsahují ještě další různé typy indikátorů:

První kategorií jsou tzv. Status indicators (Indikátory statusu/ postavení). Tyto indikátory hodnotí postavení vzdělávání pro udržitelný rozvoj v rámci země. Patři sem výhradně tzv. Baseline Indicators (základní indikátory), jejichž představiteli jsou například: počet procent nových učitelü, kterému se aktuálně dostává pregraduální prípravy ve vzdělávání pro udržitelný rozvoj počet procent nevládních neziskových organizací (jako predstavitelů neformálního vzdělávaní), které zprostředkovávají vzdělávání pro udržitelný rozvoj.

Druhou kategorií jsou tzv. Facilitative Indicators (Indikátory př́stupnosti). Účelem těchto indikátorů je vyhodnocení pomoci a podpory v oblasti vzdělávání pro udržitelný rozvoj. Do této kategorie se řadí tři typy indikátorů. Context Indicators (Indikátory kontextu), jejichž účelem je identifikovat existenci podpory v oblasti vzdělávání pro udržitelný rozvoj (např. Existence národní vzdělávací politiky, která požaduje vzdělávání pro udržitelný rozvoj v pregraduální přípravě učitelů, Existence strategie vzdělávání pro udržitelný rozvoj /udržitelného rozvoje). Dále Process Indicators (Indikátory procesu), jež slouží k popisu procesů a aktivit v oblasti vzdělávání pro udržitelný rozvoj (např. Existence kurzů pro učitele v oblasti vzdělávání pro udržitelný rozvoj - počet a obsah, \% národních korporací, které zahrnují principy udržitelného rozvoje při zapracovávání pracovníkư) a Learning Indicators (Indikátory učení), které mají reflektovat vzdělávání pro udržitelný rozvoj a popsat, jakého poučení se aplikací vzdělávání pro udržitelný rozvoj v rámci země dosáhlo (např. Jaká poučení do budoucna vzešla z aplikace pregraduálních kurzů pro učitele).

Poslední, třetí kategorií jsou Effect Indicators (Indikátory efektu/účinku). Účelem těchto indikátorů je hodnotit jevy vztahující se k aktuálním, střednědobým a dlouhodobým dosaženým výsledkům v rámci Dekády OSN vzdělávání pro udržitelný rozvoj 2005-2014. Patří sem tzv. Output Indicators (Indikátory výstupu), popisující z různých hledisek výstupy, jakými jsou učební a další materiály z kategorie vzdělávání pro udržitelný rozvoj a také bezprostřední dopady konkrétních aktivit vzdělávání pro udržitelný rozvoj (např. Počet procent učitelů, který prošel pregraduální přípravou vzdělávání pro udržitelný rozvoj). Charakterem odpovídají tyto indikátory stejně nazvanému typu indikátorů UNECE. Dalšími indikátory v této skupině jsou tzv. Outcome Indicators (Indikátory výsledku), které hodnotí změny a zlepšení, ke kterým došlo účinkem implementace vzdělávání pro udržitelný rozvoj (např. Počet procent učitelů, který ve výuce používá vzdělávací obsah a metody podporující udržitelný rozvoj, zlepšující se kompetentnost mládeže $v$ zdravém životním stylu). I tyto indikátory svým vymezením odpovídají stejně pojmenovanému typu kategorie UNECE. Do této kategorie patři dále také Impact Indicators (Indikátory dopadu), které hodnotí prímé dopady využití dané strategie v praxi (např. Aplikace principů udržitelného rozvoje $v$ denním životě u skupin, které byly v dané problematice vzdělávány. nebo Počet procent mužư a žen zastávající pozice $v$ managementu.). Posledním typem indikátorů $v$ této kategorii jsou tzv. Performance Indicators (Indikátory výkonu), které odrážejí změnu statusu vzdělávání pro udržitelný rozvoj jako celku $v$ rámci regionu nebo země (např. Nárůst počtu učitelư absolvujících pregraduální prípravu voblasti vzdělávání pro udržitelný rozvoj. nebo Nárůst počtu škol, které vzdělávání pro udržitelný rozvoj akcentují ve svých kurikulech.). Jedná se tedy o indikátory popisující trendy v dané oblasti (UNESCO Bankog, 2007).

Státům jsou spíše předloženy "směrnice" pro vytváření konkrétních indikátorů, než přímo samotné indikátory. Jsou jim tedy předkládány spíše typy indikátorů $s$ tím, že tyto jednotlivé typy jsou charakterizovány tak, aby byly pokryty dưležité aspekty vzdělávání pro udržitelný rozvoj, a jsou doprovázeny řadou ilustrativních př́kladů, které státy mohou využít při tvorbě příslušných národních indikátorů. 
Jak indikátorová sada vytvářená organizací UNECE, tak indikátorová sada vytvářená UNESCO-IUCN-CEC-Asia Pacifik zohledňují již $v$ úvodu zmiňovaný lidský hodnotový systém, tedy snaží se pomocí indikátorư výsledku (UNECE) resp. indikátorů dopadu (UNESCO) posuzovat i proměnu lidského hodnotového i postojového systému, která by měla přispět k tomu, aby se lidé (ovlivnění vzdělávacími aktivitami různého typu) chovali v souladu s myšlenkou udržitelného rozvoje. Tedy aby primárně regulovali své potřeby vưči prírodnímu prostředí. Z materiálů je však patrné, že tato oblast není jednak příliš akcentována a zejména z nich přesně nevyplývají další, přesnější indikátory, kterými by se dané aspekty mohly posuzovat. Do budoucna nicméně tyto indikátorové sady mohou přinést řadu zajímavých dat o stavu vzdělávání pro udržitelný rozvoj v jednotlivých zemích.

Za poslední, možná poněkud překvapivou skupinu indikátorů pro posuzování vzdělávání pro udržitelný rozvoj na mezinárodní úrovni, mưžeme považovat tu, která je používána ve výzkumu s názvem Program pro mezinárodní hodnocení žáků (The Programme for International Student Assessment - PISA) resp. Výzkum mezinárodních trendů $v$ matematickém a př́rodovědném vzdělávání (Trends in International Mathematics and Science Study (TIMSS $\left.{ }^{7}\right)$. Mezinárodní výzkum PISA se kromě jiného zabývá výzkumem prírodovědné gramotnosti patnáctiletých žáků, který se opakuje v pravidelných cyklech. Ve středu zájmu stojí samozřejmě žákovské vědomosti a dovednosti z oblasti přírodních věd, jejichž úroveň výzkum ověřuje prostřednictvím komplexních úloh vycházejících obvykle z běžného života. Řada úloh se týká environmentální problematiky (viz např. Frýzková and Palečková, 2007) a cílem je ověřit např. žákovské schopnosti řešit problémy související s posledně zmíněnou problematikou. Kromě toho se výzkum PISA pokouší také zmapovat žákovský postojový a hodnotový systém (pomocí dotazníků) s akcentem na vztah žákư k okolnímu přírodnímu prostředí. Výzkum navíc dále používá sadu nástrojů (zejména dotazníků) posuzujících další důležité aspekty vzdělávacích systémů zemí, jež na výzkumu participují. Tyto nástroje mají některé aspekty, které mohou být propojeny s problematikou udržitelného rozvoje. Podobný ráz má i výzkum TIMSS, který rovněž ověřuje žákovské (14 letí žáci) vědomosti a dovednosti $v$ oblasti přírodovědného vzdělávání. Výzkum TIMSS z hlediska indikátorů vzdělávání pro udržitelný rozvoj může být velmi zajímavý proto, že např. mapuje kurikula formálního vzdělávání z různých hledisek.

Ačkoli oba výzkumy slouží primárně jiným účelům, než je mapování stavu vzdělávání pro udržitelný rozvoj ve výzkumu účastnících se zemí, mohou představovat významnou mezinárodní i národní informační základnu pro toto posuzování (viz např. Stiglitz). Na rozdíl od předchozích indikátorových sad mají ty používané v těchto výzkumech dlouholeté prověření. Inspirativní jsou posledně uvedené výzkumy také proto, že našly společná východiska pro mezinárodní testování vědomostí a dovedností žáků. A to navzdory politickým, ekonomickým, kulturním a sociálním rozdílům mezi jednotlivými zeměmi, které se těchto výzkumů účastní, i rozdílům mezi jejich vzdělávacími systémy.

\section{Závěr}

Analytická studie přinesla informace o indikátorech udržitelného rozvoje z vybraných indikátorových sad, jež v sobě obsahují indikátory vzdělávání, a informace o indikátorech vzdělávání pro udržitelný rozvoj na mezinárodní úrovni. Indikátory vzdělávání, jež jsou součástí indikátorových sad monitorujících udržitelný rozvoj, mají zejména kvantitativní charakter a informace týkající se vzdělávání představují velmi obecné údaje, které jen málo vypovídají o vzdělávacích systémech daných zemí, o způsobu vzdělávání pro

7 Oba uvedené výzkumy jsou např. součástí Stiglitzovy zprávy, kde je vzdělávání součástí kapitoly Quality of Life (viz Stiglitz, 2009) 
udržitelný rozvoj nebo politice vzdělávání v daných zemích. Tyto indikátory totiž mají i jiný význam než jen přinášet důležité, nicméně pouze dílčí informace o vzdělávání v daných zemích. Monitorují také situaci např. z hlediska odstraňování nerovností mezi muži a ženami, snižování chudoby $v$ daných zemích nebo zvyšování možností $v$ prístupu k médiím $v$ zemích, kde to není běžné (indikátor přístupu k digitálním technologiím). Všechny tyto informace Ize považovat z hlediska udržitelného rozvoje za velmi podstatné a společně s dalšími indikátory monitorujícími sociální aspekt udržitelného rozvoje vytvářejí logickou strukturu. Nicméně je třeba konstatovat, že z hlediska monitoringu změny lidských potřeb nebo spíše ochoty $\mathrm{k}$ jejich regulaci, které jsme $v$ úvodu uvedli jako podstatné pro naplnění myšlenky udržitelného rozvoje, jsou tyto informace málo využitelné.

Indikátory vzdělávání pro udržitelný rozvoj jsou v současnosti na počátku vývoje a aplikace. Navržené indikátory na mezinárodní úrovni zahrnují indikátory jak kvantitativního, tak kvalitativního typu. Indikátory monitorují vzdělávání pro udržitelný rozvoj z mnoha aspektů, od aplikace př́slušných strategií národními politikami počínaje, změnami znalostí a postojů z hlediska udržitelného rozvoje konče. Lze tedy konstatovat, že indikátory vztažené ke dvěma nejdůležitějším iniciativám (UNECE a UNESCO) mají snahu aspekt změny chování lidí ve vztahu k okolnímu prostředí monitorovat. Zatímco ovšem např. monitoring způsobu aplikace národními politikami (založený jak na kvantitativních datech, tak na kvalitativním popisu situace) nebo monitoring způsobu podpory implementace národních strategií je rozpracován do značné míry, pak právě tolik důležitý aspekt, jakým je změna znalostí $v$ tomto směru a zejména pak postojů vưči okolnímu prostředí, př́liš rozpracován není. A to, vzhledem k tomu, že v řadě případů se může implementace strategií nebo iniciativ promítnout až na úroveň formálního vzdělávání, jak jsme ilustrovali v kapitole 3, je značný nedostatek těchto indikátorových sad.

Ačkoli se zdá být velmi složité vytvořit systém monitoringu změn lidských znalostí o okolním prostředí či monitoringu změn lidského chování a jednání vưči okolnímu prostředí na mezinárodní úrovni z důvodu velkých sociálních, ekonomických a kulturních rozdílů mezi jednotlivými zeměmi, bylo by zřejmě zajímavé postupovat podobným způsobem, jakým toto činí mezinárodní organizace aplikující výzkumy PISA a TIMSS (i s přihlédnutím k některý problémům, které tyto výzkumy přinášejí). Tyto výzkumy stojí v centru zájmu národních vzdělávacích politik zemí, které se daných výzkumů zúčastňují, a Ize se domnívat, že podobný zájem by decisní sféra projevila i o výsledky, které by logicky tyto výzkumy doplňovaly. Tedy o výsledky z výzkumů v oblasti vzdělávání pro udržitelný rozvoj.

Právě monitoring změn znalostí jedinců o udržitelném rozvoji, jakož i změn jejich jednání a chování vưči okolnímu prostředí v důsledku jejich vzdělávání (ve všech jeho rovinách), tedy vytváření indikátorů vztahujících se k tomuto jevu, by mohlo postupně doplnit nejen existující indikátory vzdělávání pro udržitelný rozvoj na mezinárodní úrovni, ale posléze také indikátory udržitelného rozvoje (viz obrázek 1). Vznikl by tak logicky provázaný systém indikátorů vztahující se k uvedené hierarchii lidských potřeb zmíněné v úvodu tohoto článku, tedy indikátorů pro monitoring ochoty regulace lidských potřeb (vázaných na vzdělávání ve všech jeho rovinách). Takový logicky provázaný systém v současnosti citelně chybí.

Obr. 1 - Komplexní monitoring vzdělávání ve vztahu k problematice udržitelného rozvoje (UR) 


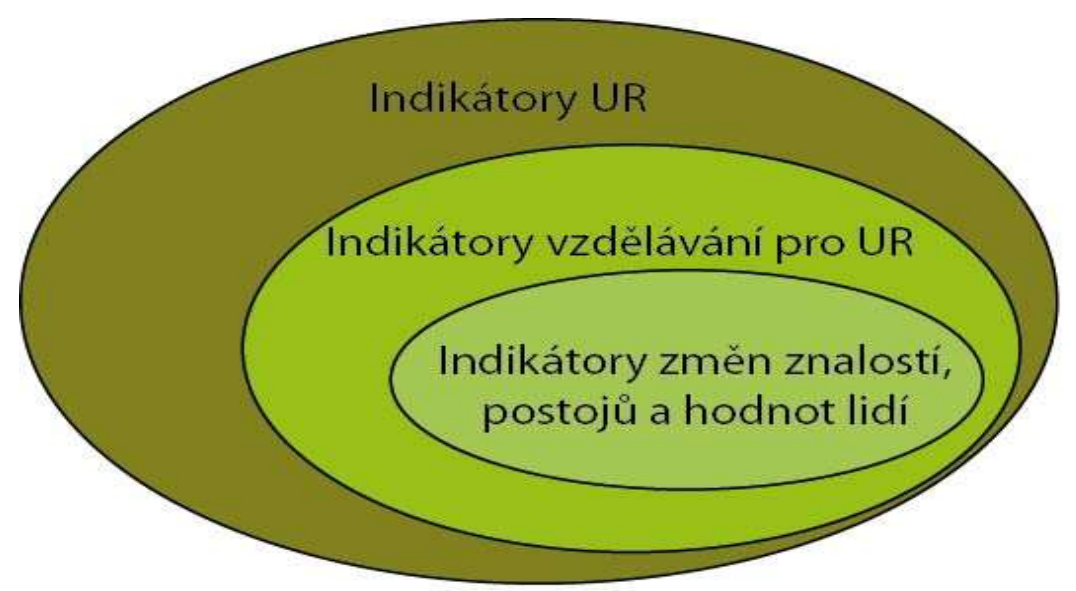

Tab. 1 Přehled vybraných mezinárodních strategií, cílů/principů/zásad vztahujících se $k$ tematice vzdělávání pro udržitelný rozvoj v širším kontextu

\begin{tabular}{|c|c|}
\hline Název dokumentu & Zásady/cíle/politiky spojované s určitou formou vzdělávání \\
\hline $\begin{array}{l}\text { Deklarace o životním } \\
\text { prostředí a rozvoji z Ria, } \\
1992 \\
\text { (Rio Declaration on } \\
\text { Environment and } \\
\text { Development, 1992) }\end{array}$ & 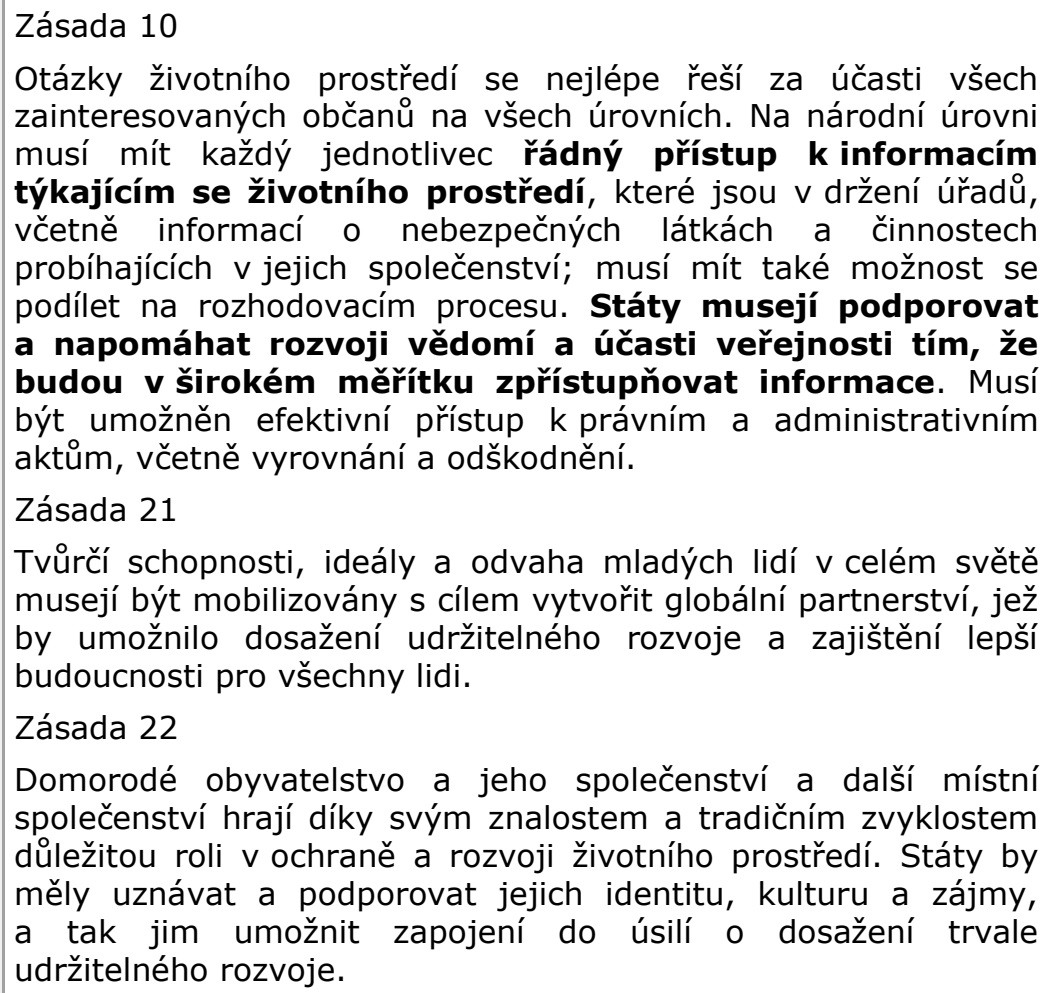 \\
\hline $\begin{array}{l}\text { Agenda } 21 \text { ( Akční } \\
\text { program OSN pro } \\
21 . \text { století), } 1993\end{array}$ & $\begin{array}{l}\text { Př́klad rozpracování zásady } 10 \text { deklarace z Ria: } \\
\text { Programová oblast: Integrace životního prostředí a rozvoje do } \\
\text { rozhodování na politické, plánovací a řídící úrovni (Část sociální } \\
\text { a ekonomický rozměr) }\end{array}$ \\
\hline Agenda 21 (The UN & Zvyšování povědomí veřejnosti \\
\hline
\end{tabular}


Programme of Action from Rio), 1993

Strategie OECD pro životní prostředí pro první desetiletí 21 . století, 2001

OECD Environmental Strategy for the first Decade of the 21 th Century, 2001

Udržitelnou Evropou za lepší svět: Strategie udržitelného rozvoje Evropské unie, 2001

EC A sustainable Europe for a better World: A European Union

Strategy for Sustainable Development, 2001

Obnovená strategie udržitelného rozvoje EU, 2006

Renewed EU Sustainable Development Strategy, 2006
8.11. Jednotlivé státy by měly, ve spolupráci s národními institucemi a skupinami, médii a ve spolupráci s mezinárodním společenstvím, osvětově působit na velké skupiny i na jednotlivé specifické okruhy veřejnosti, a měly by tak rozvíjet vědomí důležitosti integrovaného -neoddělovaného- chápání životního prostředí a rozvoje; měly by rovněž vytvářet mechanismy usnadňující přímou výměnu informací a názorů s veřejností. Na předním místě by mělo být objasňování zodpovědnosti a potenciálního příspěvku různých sociálních skupin.

Cíl 4: Sociální a environmentální propojenost: zvýšení kvality života

(Vybrané) národní aktivity zemí OECD s ohledem na informace, participaci, přístup $k$ právní ochraně $v$ záležitostech životního prostředí a environmentálnímu vzdělávání.

1. Prosazovat informovanost a environmentální vzdělávání jako předpoklad pro identifikaci, přijetí a úspěšnou implementaci environmentální politiky.

4. Posílení environmentálního vzdělávání a učení na všech úrovních, prostřednictvím obcí a iniciativ na pracovištích.

Kapitola II - Realizace udržitelného rozvoje: dosažení našich ambicí

(oddíl: Zlepšení komunikace a mobilizovat občany a podniky)

Národní aktivita:

Členské státy by měly posoudit, jak jejich vzdělávací systém může pomoci hlubšímu porozumění konceptu udržitelného rozvoje.

Průřezové politiky vedoucí ke znalostní společnosti

Vzdělávání a odborná příprava

Vzdělávání je předpokladem pro podporu změn chování a poskytování takových klíčových kompetencí všem občanům, které jsou nutné pro dosažení udržitelného rozvoje. Úspěch ve zvrácení neudržitelných trendů společnosti bude do značné míry záviset na vysoce kvalitním vzdělávání pro udržitelný rozvoj na všech úrovních vzdělávání, zahrnující vzdělávání v takových tématech, jakými jsou udržitelná spotřeba energií a dopravního systému, vzorce udržitelné spotřeby a výroby, zdraví, mediální kompetence a zodpovědné globální občanství.

Vzdělávání může vést $\mathrm{k}$ větší sociální kohezi a blahobytu a to díky investicím do sociálního kapitálu a při zajištění rovných př́ležitostí, a participaci občanů, zvláště ze znevýhodněných skupin, na získávání většího stupně informovanosti a pochopení komplexnosti a mnoha vzájemných souvislostí současného světa. Vzdělávání, které poskytne ženám a mužưm takové kompetence, které zvýší jejich zaměstnatelnost a povede ke zvýšení kvality zaměstnání je rovněž klíčová v posilování konkurenceschopnosti EU.

V souvislosti s UN dekádou pro udržitelný rozvoj (2005-2014) mohou členské státy dále rozvíjet vlastní akční plány, zejména s využitím pracovního programu "Education and training 2010", 
jehož cíle jsou zaměřeny na kvalitu a relevanci (vzdělávání), na prístup (ke vzdělávání) pro všechny a na otevřenost systému a institucí veřejnosti a širšímu světu. Členské státy by mohly vyvíjet vzdělávání pro udržitelný rozvoj a cílené odborné vzdělávání pro profese $v$ odvětvích, jakými jsou stavebnictví, nebo energetika a doprava. Speciální pozornost by měla být věnována př́pravě učitelů. ....

Tab. 3 - Přehled strategií vzdělávání pro udržitelný rozvoj a jejich cílů

\begin{tabular}{|c|c|}
\hline Název strategie & $\begin{array}{l}\text { Cíle a prostředky k jejich dosažení přijaté v rámci } \\
\text { strategie }\end{array}$ \\
\hline $\begin{array}{l}\text { Strategie vzdělávání pro } \\
\text { udržitelný rozvoj, Vilnius, } \\
\text { 2005, UNECE }\end{array}$ & 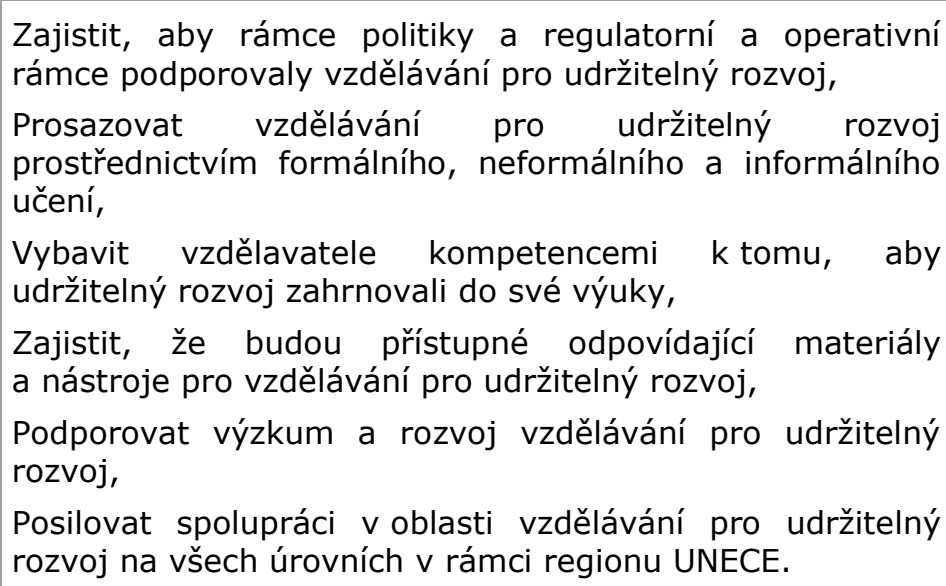 \\
\hline $\begin{array}{l}\text { Dekáda OSN vzdělávání pro } \\
\text { udržitelný rozvoj } 2005 \text { - } \\
\text { 2014, UNESCO }\end{array}$ & 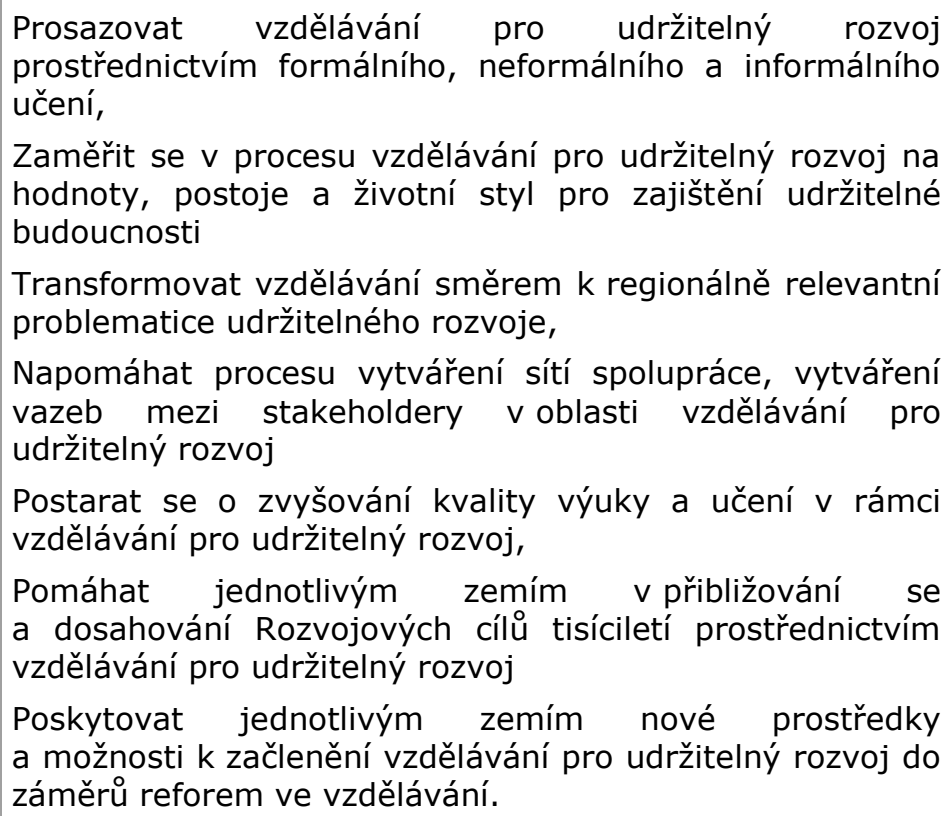 \\
\hline
\end{tabular}


Tab. 2 - Přehled indikátorových sad udržitelného rozvoje zahrnujících aspekt vzdělávání

\begin{tabular}{|c|c|}
\hline Indikátorová sada & Typ indikátoru \\
\hline $\begin{array}{l}\text { Index environmentální } \\
\text { udržitelnosti } \\
\text { Environmental } \\
\text { Sustainability Index }\end{array}$ & $\begin{array}{l}\text { Název indikátoru: Věda a technologie } \\
\text { Sledované parametry*: } \\
\text { Index přístupu k digitálním technologiím. } \\
\text { Poměr žen s dokončeným primárním vzděláváním. } \\
\text { Poměr zapsaných jedinců v terciárním vzdělávání. } \\
\text { Počet výzkumných pracovníků na milion obyvatel. } \\
\text { Název indikátoru: Environmentální politika } \\
\text { Sledované parametry: } \\
\text { Znalosti získané v oblasti environmentální vědy, technologií } \\
\text { a postupư. }\end{array}$ \\
\hline $\begin{array}{l}\text { Rozvojové cíle tisíciletí } \\
\text { OSN } \\
\text { United Nations Millenium } \\
\text { Development Goals }\end{array}$ & 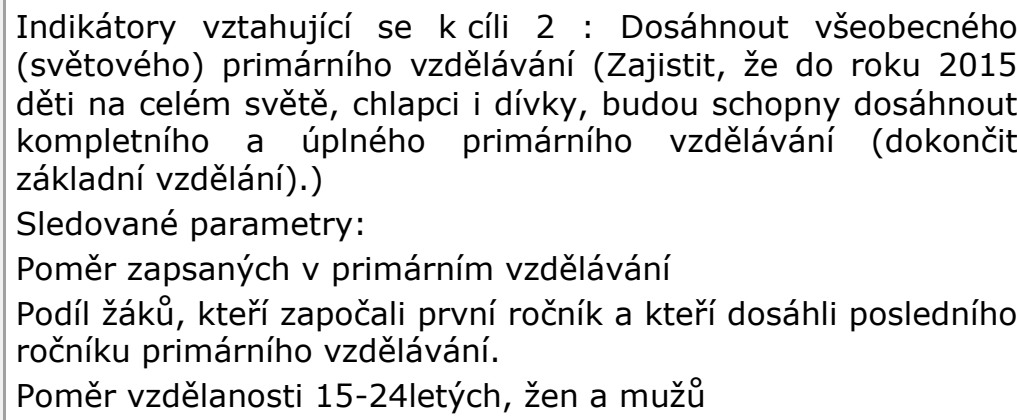 \\
\hline $\begin{array}{l}\text { Index lidského rozvoje } \\
\text { Human Development } \\
\text { Index }\end{array}$ & $\begin{array}{l}\text { Sledované parametry: } \\
\text { Kombinovaný poměr zápisu do škol } \\
\text { Obsahuje subkategorie: gramotnost obyvatelstva staršího } 15 \\
\text { let ( } 2 / 3 \text { hodnoty indikátoru) a počet přihlášených dětí na školy } \\
\text { prvního, druhého a třetího stupně ( } 1 / 3 \text { hodnoty indikátoru) }\end{array}$ \\
\hline $\begin{array}{l}\text { OECD - Měření } \\
\text { společenského pokroku } \\
\text { OECD - Measuring the } \\
\text { Progress of Societies }\end{array}$ & $\begin{array}{l}\text { Sledovaná oblast/cíl (vlastní indikátory nevyvíjejí, vycházejí } \\
\text { a srovnávají měření hodnot na mezinárodní a národní úrovni } \\
\text { - např.Canadian progress of wellbeing, Measuring Ireland s } \\
\text { progress, Indicators of social progress, Hungary Etc.): } \\
\text { Lidský blahobyt: výstupy pro lidi (Human well-beeing: } \\
\text { outcomes for people) } \\
\text { Znalosti a pochopení }\end{array}$ \\
\hline $\begin{array}{l}\text { Komise pro udržitelný } \\
\text { rozvoj OSN - } \\
\text { Indikátory } \\
\text { udržitelného rozvoje } \\
\text { (indikátory určené pro } \\
\text { potřeby národních politik } \\
\text { v oblasti udržitelného } \\
\text { rozvoje) } \\
\text { UN-CSD Indicators of } \\
\text { Sustainable development }\end{array}$ & $\begin{array}{l}\text { Podtéma: Úroveň vzdělávání } \\
\text { Sledované parametry: } \\
\text { Hrubý poměr přijatých osob do posledního ročníku primárního } \\
\text { vzdělávání } \\
\text { Čistý poměr přijatých v primárním vzdělávání } \\
\text { Stupeň dosaženého sekundárního (terciárního) vzdělání } \\
\text { u dospělých. } \\
\text { Podtéma: Gramotnost } \\
\text { Sledované parametry: } \\
\text { Poměr gramotnosti dospělých }\end{array}$ \\
\hline
\end{tabular}
se vzděláváním. 


\section{Literatura:}

- Dlouhá, J. (2008). Indikátory pro strategie environmentálního vzdělávání. Envigogika, 2(3), Retrieved from http://www.envigogika.cuni.cz/envigogika-2007-ii-3/indikatory-pro-strategieenvironmentalniho-vzdelavani cS

- Giovanni, E., Hall, J., Morrone, A., \& Ranuzzi, G. (2009). A Framework to measure the progress of societies, Draft OECD working Paper. Paris: OECD.

- EC: A sustainable Europe for a better world: A European Union Strategy for Sustainable Development, COM (2001) (2001). Brussels.

- EU: Renewed EU sustainable development strategy 10917/06. (Adopted by the European Council 15/16 June 2006) (2006). Brussels.

- IUCN; UNEP ; WWF World Conservation Strategy, International Union for the Conservation of Nature, Gland (1980). .

- Frýzková, M., \& Palečková, J. (2007). Prírodovědné úlohy výzkumu PISA. Praha: ÚIV - Tauris.

- Janoušková, S., \& Maršák, J. (2008). Indikátory - významný prostředek našeho poznávání. Pedagogika, 58(1), 29-35.

- Maslow, H. A. (1968). Toward Psychology of Being. New York: John Wiley and Sons.

- Strategie vzdělávání pro udržitelný rozvoj České republiky (2008 - 2015) . . Retrieved from http://www.mzp.cz/C1257458002F0DC7/cz/strategie vzdelavani/\$FILE/OEVStrategie VUR \%C4\%8CR-20080808.pdf

- Ogawa, R., \& Collom, E. (2000). Using Performance Indicators to Hold Schools Accountable: Implicit Assumptions and Inherent Tensions. Peabody Journal of Education, 75(4), 200-215.

- Oecd, (2001). OECD Environmental Strategy for the First Decade of the 21st Century. Paris: OECD.

- Průcha, J. . Přehled Pedagogiky: Úvod do studia oboru. Praha: Portál.

- Rámcový vzdělávací program pro základní vzdělávání (2005). Praha: Výzkumný ústav pedagogický v Praze, Tauris.

- Rámcový vzdělávací program pro gymnázia (2007). Praha: Výzkumný ústav pedagogický v Praze.

- Shavelson, R. J., McDONNEL, L., \& Oaks, J. (1991). What are educational indicators and indicator systems?. Practical Assessment, Research and Evaluation,2(11), Retrieved from http://pareoline.net/getvn.asp?v=2\&n=11 . ISSN 1531-7714

- Stiglitz, J., Sen, A., \& Fotoussi, J. P. (2009). Report by the Commission on the Measurement of Economic Performance and Social Progress. Brussels: European Commission.

- Šremer, P. (2007). Některé aspekty vývoje k udržitelnosti. Envigogika, 2(3), Retrieved from http://www.envigogika.cuni.cz/envigogika-2007-ii-3/nektere-aspekty-vyvoje-kudrzitelnosti CS

- Tilbury, D. (2007). Monitoring and Evaluation during the UN Decade of Education for Sustainable Development. Journal of Education for Sustainable Development, 1(2), 239-254. Retrieved from http://jsd.sagepub.com/cgi/doi/10.1177/097340820700100214 http://dx.doi.org/10.1177/097340820700100214

- UN - Department of Economic and Social Affairs, (2007). Indicators of Sustainable Development: Guideline and Metodologies. New York: United Nations.

- Unece, (2005). Strategie pro vzdělávání pro udržitelný rozvoj. Vilnus: UNECE. Retrieved from http://www.unece.org/env/esd/strategytext/strategyinczech.pdf 
- UNESCO-UNEP CONGRESS: Environmental Education and training: International Strategy for Action in the field of Environmental Education and Training for the 1990s (1987). Paris: United Nations Educational, Scientific and Cultural Organization, Paris.

- Bankog, U. (2007). Asia-Pacific Guidelines for the Development of National ESD Indicators. Bankog: UNESCO Bankog.

- Unesco, (2007). The UN Decade of Education for Sustainable Development (DESD 2005 2014), The FirstTwo Years. : UNESCO.

- Unesco, (2009). Review of Contexts and Structures for Education for Sustainable development. Paris: UNESCO Section for DESD Coordination.

- Unced, (1992). Rio Declaration on Environment and Development, Report of the United Nations Conference on Environment and Development, August 12, 1992, A/CONF.151/26 (Vol.1). .

- Development, W. C. O. E. a. (1987). Our Common Future. Oxford: Oxford University Press.

- Who, (2003). Diet, Nutrition and Prevention of Chronic Diseases: Report of a Joint WHO/FAO Expert consultation. Geneva: WHO Technical Report Series 916. 
Časopis Envigogika vydává Centrum pro otázky životního prostředí UK. Vývoj časopisu je podpořen projektem OP VK Mezioborová sít udržitelného rozvoje.

Více najdete na internetových stránkách projektu mosur.czp.cuni.cz
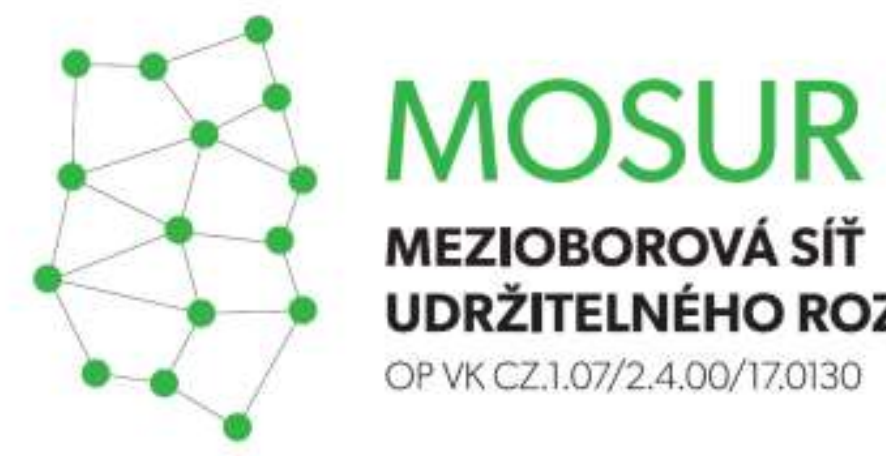

\section{MEZIOBOROVÁ SÍT} UDRŽITELNÉHO ROZVOJE

OP VK CZ.1.07/2.4.00/17.0130
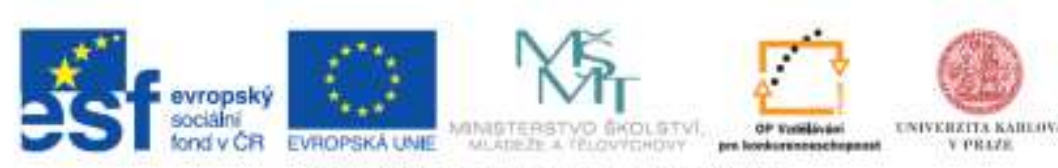

INVESTICE DO ROZVOUE VZDELAVANI 